\title{
Front Matter: Volume 11767
}

, "Front Matter: Volume 11767," Proc. SPIE 11767, 2020 International Conference on Optoelectronic Materials and Devices, 1176701 (26 January 2021); doi: $10.1117 / 12.2593121$

SPIE Event: 2020 International Conference on Optoelectronic Materials and SPIE. Devices, 2020, Guangzhou, China 


\title{
PROCEEDINGS OF SPIE
}

\section{ICOMD 2020: Optoelectronic Materials and Devices}

\author{
Pei Wang \\ Siting Chen \\ Editors
}

\section{8-20 December 2020 \\ Guangzhou, China}

Sponsored by

University of Science and Technology of China

Organized by

AEIC Academic Exchange Information Centre (China)

Published by

SPIE 
The papers in this volume were part of the technical conference cited on the cover and title page. Papers were selected and subject to review by the editors and conference program committee. Some conference presentations may not be available for publication. Additional papers and presentation recordings may be available online in the SPIE Digital Library at SPIEDigitalLibrary.org.

The papers reflect the work and thoughts of the authors and are published herein as submitted. The publisher is not responsible for the validity of the information or for any outcomes resulting from reliance thereon.

Please use the following format to cite material from these proceedings:

Author(s), "Title of Paper," in 2020 International Conference on Optoelectronic Materials and Devices, edited by Pei Wang, Siting Chen, Proceedings of SPIE Vol. 11767 (SPIE, Bellingham, WA, 2021) Seven-digit Article CID Number.

ISSN: 0277-786X

ISSN: 1996-756X (electronic)

ISBN: 9781510643666

ISBN: 9781510643673 (electronic)

Published by

SPIE

P.O. Box 10, Bellingham, Washington 98227-0010 USA

Telephone +1 3606763290 (Pacific Time) · Fax +1 3606471445

SPIE.org

Copyright (c) 2021, Society of Photo-Optical Instrumentation Engineers.

Copying of material in this book for internal or personal use, or for the internal or personal use of specific clients, beyond the fair use provisions granted by the U.S. Copyright Law is authorized by SPIE subject to payment of copying fees. The Transactional Reporting Service base fee for this volume is $\$ 21.00$ per article (or portion thereof), which should be paid directly to the Copyright Clearance Center (CCC), 222 Rosewood Drive, Danvers, MA 01923. Payment may also be made electronically through CCC Online at copyright.com. Other copying for republication, resale, advertising or promotion, or any form of systematic or multiple reproduction of any material in this book is prohibited except with permission in writing from the publisher. The CCC fee code is $0277-$ $786 \mathrm{X} / 21 / \$ 21.00$.

Printed in the United States of America by Curran Associates, Inc., under license from SPIE.

Publication of record for individual papers is online in the SPIE Digital Library.

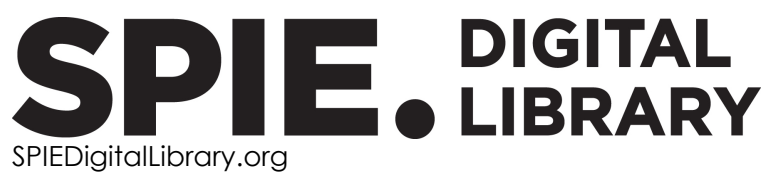

Paper Numbering: Proceedings of SPIE follow an e-First publication model. A unique citation identifier (CID) number is assigned to each article at the time of publication. Utilization of CIDs allows articles to be fully citable as soon as they are published online, and connects the same identifier to all online and print versions of the publication. SPIE uses a seven-digit CID article numbering system structured as follows:

- The first five digits correspond to the SPIE volume number.

- The last two digits indicate publication order within the volume using a Base 36 numbering system employing both numerals and letters. These two-number sets start with $00,01,02,03,04$, 05, 06, 07, 08, 09, OA, OB ... 0Z, followed by 10-1Z, 20-2Z, etc. The CID Number appears on each page of the manuscript. 


\section{Contents}

NEW PHOTOELECTRIC PREPARATION AND PHOTOELECTRIC CONVERSION TECHNOLOGY APPLICATION

1176702 Analysis of factors affecting homogenization effect of homogenizing rod in laser lighting system [11767-1]

1176703 An implementation of the wireless power transfer by the laser technology [11767-2]

$1176704 \quad$ Research and design of vehicle inverter power supply based on DSP [11767-3]

1176705 Research on sound absorption performance of ultra-thin metal micro-perforated panel absorber [11767-4]

1176706 Study on autofluorescence characteristics of micro droplet digital PCR chip [11767-7]

1176707 Mid-infrared thermal detector based on Au-disk structure and vanadium dioxide [11767-10]

$1176708 \quad$ Enhanced forward stimulated Brillouin scattering in aluminum nitride slot waveguides with acoustic pumping [11767-12]

1176709 Cascaded Brillouin lasing in a suspended silicon racetrack micro-ring pumped by external fiber loop [11767-13]

11767 OA Time domain characteristic analysis of wind turbine tower load based on imbalanced fault of wind wheel [11767-15]

11767 OB Photoluminescence study of GaAs nanowires with and without AIGaAs shell [1 1767-16]

11767 OC A hybrid KA-MoM method for scattering from dielectric target above a dielectric rough surface [11767-17]

11767 OD Static and dynamic test of narrow pulse laser fuze detection system [11767-19]

$11767 \mathrm{OE} \quad$ Design and implementation of high precision semiconductor laser drive system based on MAX1978 [11767-22]

11767 OF Measurement and calculation of passive intermodulation nonlinear coefficient [11767-24]

11767 OG Measuring retroreflected chromaticity coordinates of retroreflective sheeting [11767-27]

$11767 \mathrm{OH} \quad$ Study the preparation method of cathode foil of solid-state aluminum capacitor [11767-36] 
$11767 \mathrm{Ol} \quad$ The dual-wavelength ratio temperature measurement through helical long-period gratings [1 1767-45]

$117670 \mathrm{~J} \quad$ Application of beam expanding fiber technology in military vehicle-mounted optical link [1 1767-46]

11767 OK Study on dynamic characteristics of eccentric motorized spindle [1 1767-47]

$11767 \mathrm{OL} \quad$ In/N-codoping synergistic effects on electronic structures of anatase titania: a first-principles calculation [11767-48]

11767 OM Design of remote wireless collection system for multi-meter based on narrow band Internet of Things [1 1767-50]

11767 ON Simulation and optical optimization of deep-sea hydrothermal velocity measurement system [1 1767-52]

1176700 Servo circuit of quartz flexible accelerometer with low power consumption and high integration [1 1767-57]

11767 OP Preparation and research of concrete shrinkage reducing agent [11767-59]

$117670 Q \quad$ Study on measurement technology of stray light signal in space optical imaging system [11767-60]

11767 OR Design and optimization of Hilbert fractal antenna for corona discharge detection of highvoltage transmission lines [1 1767-68]

11767 OS Seismological system fault detection technology based on waveform analysis [11767-70]

11767 OT A high power and wavelength tunable mid-infrared laser with a high-precision power attenuator [11767-74]

11767 OU A dual-frequency horizontally polarized omnidirectional antenna for WLAN applications [1 1767-75]

11767 OV Research on electromagnetic protection of laser fuze receiving system [1 1767-80]

11767 OW Recent advancements in the synthesis and application of PEDOT and PEDOT:PSS [11767-82]

INTELLIGENT DEVICE EQUIPMENT AND MACHINE VISION IMAGE ANALYSIS

11767 OX Research on demodulation technology of air acoustic sensor based on DFB-FL [11767-5]

11767 OY Simultaneous measurement of hydrogen and humidity based on an integrated FBG sensor [11767-6]

$11767 \mathrm{OZ}$ Development and validation of 100,000km maintenance-free transmission oil [1 1767-8] 
1176710 Research on measurement of underwater vehicle noise with single vector hydrophone [1 1767-9]

1176711 Cooling strategy and experiment of high-speed motorized spindle [11767-14]

1176712 Analysis on the application, development, and future prospects of Gallium Nitride (GaN) [11767-18]

1176713 Design and simulation optimization of bionic flapping-wing robot [11767-20]

1176714 Study on gain and noise of TDM-pumped fiber Raman amplifier [11767-21]

$1176715 \quad$ Uniaxially tensile strained Ge/SiGe coupled quantum wells [11767-23]

1176716 Research on multi-excitation pulsed airborne electromagnetic transmitter [11767-25]

1176717 Design of broadband microstrip equalizer [11767-26]

1176718 Retroreflective distribution measurements and analysis of road traffic markings [11767-28]

1176719 Structural optimization scheme based on the linkage mechanism of a rail grinding car [11767-30]

$117671 \mathrm{~A}$ Research on sensor state evaluation and fault diagnosis based on multi-dimensional information fusion [11767-31]

11767 1B Analysis of resonance influence of capacitor voltage transformer and protective measures [11767-32]

11767 1C Design of electromagnetic pulse crimping device [11767-34]

11767 1D Small target detection method with high accuracy for visible colony RGB image formed by bacteria in water [11767-35]

$117671 \mathrm{E} \quad$ Intelligent detection method of DR detection equipment assembly defects based on $x$-ray digital imaging [11767-38]

11767 IF Spin-valve effect in Py/MoSe 2 Co junctions [11767-39]

$117671 \mathrm{G}$ Integrated optical filter consisting of micro-ring resonator embedded in Fabry-Perot cavity [11767-40]

$117671 \mathrm{H} \quad$ Development of seven-electrode conductivity sensor for seawater [11767-41]

$1176711 \quad$ A kind of novel miniaturized millimeter-wave waveguide divider [1 1767-42]

$11767 \mathrm{lJ} \quad$ Multi-radiators for scattering from coated flat plate in half space [11767-44] 
$117671 \mathrm{~K} \quad$ Hydrogeological characteristics analysis of typical coal mines in Hancheng mining area of China [11767-51]

$117671 \mathrm{~L} \quad$ Investigation of narrowband tunable filter based on multilayer waveguide structure [1 1767-55]

$117671 \mathrm{M}$ Intelligent classification robot based on image recognition [11767-56]

$117671 \mathrm{~N}$ Research on the development of titanium alloy recovery technology in civil aviation industry [1 1767-58]

1176710 Analysis of electrical contact surface characteristics of aeronautical electrical circuit based on infrared thermography [11767-61]

11767 1P Analysis of the influence of bearing seat clearance on axial force in Shaogang $3450 \mathrm{~mm}$ plate rolling mill [1 1767-62]

$117671 Q \quad$ Comparative study on integrated air data system of civil aircraft [11767-64]

$117671 \mathrm{R} \quad$ Numerical simulation research on the ash pollution measurement sensor based on coplanar capacitance principle [11767-67]

11767 is Present situation and countermeasures of intellectual property awareness education in vocational college [11767-69]

$117671 \mathrm{IT} \quad$ Study on aging of polyurethane in elevator buffer [11767-76]

$117671 \mathrm{U} \quad$ Burst failure analysis of a convection tube [11767-77]

11767 IV Investigation on creep rupture behavior of SA387Gr91 steel welded joint [11767-78]

$11767 \mathrm{lW} \quad$ Experimental study of strain strengthening \$30408 under liquid nitrogen temperature [1 1767-79] 